\title{
EVALUATION OF IN VIVO ANTICANCER AND IMMUNOSTIMULATORY ACTIVITY OF FLOWERS OF MIMOSA PUDICA LINN. (FABACEAE)
}

\author{
DEBAPROTIM DASGUPTA ${ }^{1 *}$, SUVAKANTA DASH ${ }^{2}$
}

${ }^{1}$ Department of Pharmaceutical Chemistry, Girijananda Chowdhury Institute of Pharmaceutical Science, Azara, Hathkhowapara, Guwahati - 781 017, Assam, India. 'Department of Pharmaceutics, Girijananda Chowdhury Institute of Pharmaceutical Science, Azara, Hathkhowapara, Guwahati - 781 017, Assam, India. Email: Sdash77@gmail.com

Received: 16 March 2017, Revised and Accepted: 14 April 2017

ABSTRACT

Objective: To investigate the in vivo anticancer and immunostimulatory activity of dichloromethane (DCM) extract of flowers of Mimosa pudica and its isolated compound $11 \beta$ hydroxy-3 methoxy 1,2 dehydro crinane.

Methods: The anticancer activity was performed on Ehrlich ascites carcinoma (EAC) cell line in Swiss albino mice. The activity was assessed by evaluating tumor volume, viable and nonviable tumor cell count, tumor weight, hematological, and histopathological parameters of EAC-bearing animals. The immunostimulatory activity was performed through carbon clearance, delayed type hypersensitivity (DTH), neutrophil adhesion and humoral antibody (HA) titer methods.

Results: At the dose of 500 and $1000 \mathrm{mg} / \mathrm{kg} /$ day p.o for the extracts and $2.5 \mathrm{mg} / \mathrm{kg} /$ day p.o. for the isolated compound, significantly decrease the tumor volume $(3.46 \pm 0.135 \mathrm{ml}, 2.25 \pm 0.153 \mathrm{ml}$, and $1.84 \pm 0.012)$, increased the life span $(59.32 \%, 76.39 \%$, and $82.43 \%$ ) and significantly (p<0.05) decreased tumor weight as compared with control. Hematological profiles were found to be nearly normal level in extract treated mice compared with tumor bearing control mice. The immunostimulatory activity was also found to be effective in the above dosage regimen. The results revealed that animals treated with above doses show a significant increase in the rate of carbon clearance from blood, increase in HA titer value, increase in neutrophil adhesion and significant $(\mathrm{p}<0.05)$ increase in mean paw edema in DTH reactions in dose-dependent manner.

Conclusion: The results demonstrated that the extract is possessing dose-dependent anticancer activity and immunostimulatory activity attributed to the presence of crinane alkaloid.

Keywords: Humoral antibody titer, Ehrlich ascites carcinoma cell line, LD $_{50}$, Delayed type hypersensitivity, Dichloromethane, Mimosa pudica.

(c) 2017 The Authors. Published by Innovare Academic Sciences Pvt Ltd. This is an open access article under the CC BY license (http://creativecommons. org/licenses/by/4. 0/) DOI: http://dx.doi.org/10.22159/ajpcr.2017.v10i7.18514

\section{INTRODUCTION}

Cancer is the prominent cause of mortality worldwide, and most of the chemotherapeutic agents have been reported to exhibit severe toxicity to normal tissues, accompanied by undesirable huge side effects [1]. Moreover, most of these drugs are very expensive, mutagenic, and carcinogenic. Therefore, novel pharmaceutical agents that provide a more specific therapeutic regimen or increase the efficacy of conventional chemotherapy, without increasing toxicity toward normal cells, would clearly be of great clinical benefit. Increasing evidence suggests that immune responses are involved in the control of cancer and that the immune system can be manipulated in different ways to recognize and treat cancers [2]. Progress in immune-based strategies has introduced a new therapeutic avenue using a number of techniques destined to eliminate malignant cells [3]. Recently, cancer chemoprevention with ideas using foods and medicinal herbs has been regarded as one of the most visible fields for cancer control [4]. Most of the anti-tumor drugs currently used in chemotherapy are toxic to normal cells and cause toxicity for immune cells. Therefore, the identification of new anticancer drug with low side effects on the immune system or which boosts it has become an essential goal in many studies of immunopharmacology.

The Mimosa pudica Linn. (Fabaceae) invites the attention of the researchers worldwide for its traditional use in various parts of the world. In Assam part of India, it is known by the name "Lajukilata" and traditionally used as antitumor, stimulant, antioxidant and for wound healing activity. Phytoconstituents such as alkaloids, sterols, and tannins together with other compounds such as mimosine, mimosinic acid, and gallic acid were already reported from this plant [5]. Although some studies are reported on anticancer activity of leaves and aerial plant parts extracts of $M$. pudica but no studies were conducted with the flowering parts of the plants. This study was undertaken to explore the anticancer and immunostimulatory property of flowers of M. pudica Linn using some in vivo models.

\section{EXPERIMENTAL}

\section{Plants material}

Flower parts of M. pudica were collected from local areas of Guwahati, Assam, India in the month of January 2012. The plant material was authenticated by Dr. GC Sharma, Curator, Department of Botany, Gauhati University, Guwahati (voucher specimen no. 17777).

\section{Preparation of the extracts}

The collected plant parts were washed with water; shade dried in open air and pulverized using an electric grinder. About $200 \mathrm{~g}$ of $M$. pudica powder was packed into Soxhlet apparatus and subjected to successive extraction using petroleum ether, ethyl acetate, dichloromethane (DCM), and butanol as the solvent. The preliminary phytochemical and pharmacological screening shows a good result for DCM extract, therefore it is selected for further studies. The extract was filtered through Whatman filter paper No. 40, evaporated using vacuum rotary evaporator (Buchi) and heated on a water bath at $45 \pm 5^{\circ} \mathrm{C}$ and stored in vacuum desiccators for further use [6,7].

\section{Isolation of compound}

M. pudica flower DCM extracts were fractioned by column chromatography using silica gel $60-120$ as stationary phase and 
methanol-chloroform as mobile phase. The isolated compound was purified using preparative thin layer chromatography (TLC) techniques. The spot of the compound was scraped, collected, and then diluted with chloroform:methanol (7:3). The compound was obtained in the form of a crystal after filtration and evaporation. It was identified by ultraviolet, Fourier-transform infrared, nuclear magnetic resonance, and mass spectroscopic methods. The compound is identified as $11 \beta$ hydroxy- 3 methoxy 1,2 dehydro crinane.

\section{Drugs and chemicals}

Extra immune tablets (Charak pharmaceuticals) and cyclophosphamide in the form of cycloxan-50 tablet (Biochem Pharmaceuticals) were locally purchased from the medicine store. Trypan blue was purchased from Hi media Laboratories Pvt. Ltd, Mumbai. Nylon fiber purchased from local market Guwahati, Assam, India. Methotrexate was obtained from IPCA Laboratories, Mumbai.

\section{Animals}

The study was conducted using Swiss albino mice weighing $20 \pm 5 \mathrm{~g}$. They were obtained from the animal house of GIPS. The mice were grouped, housed in polycrylic cages and maintained under standard laboratory conditions (temperature $25 \pm 2^{\circ} \mathrm{C}$ ) with light/dark cycle $(12 / 12 \mathrm{hr})$. They were allowed free access to a standard dry pellet diet and water ad-libitum [8].

\section{Acute toxicity study}

The acute toxicity study was conducted as per the OECD guidelines 425. Initially, the DCM extract was administered orally at a limit dose of $2000 \mathrm{mg} / \mathrm{kg}$ for the extract and $10 \mathrm{mg} / \mathrm{kg}$ for the isolated compound to single mice. The mice were observed closely for the first $4 \mathrm{hr}$ and then periodically up to $24 \mathrm{hr}$ for any toxic symptoms and mortality. After $24 \mathrm{hr}$ same dose was administered to four more female rats. This study was approved by the Animal Ethics Committee of Girijananda Chowdhury Institute of Pharmaceutical Sciences, Guwahati, Assam (CPCSEA Regn. No.1372/C/10/CPCSEA. Study approval No-GIPS/ IAEC/07). The acute toxicity study was conducted for $24 \mathrm{hrs}$.

\section{Anticancer activity of DCM extract of $M$. pudica}

\section{Experimental protocol}

For this study, animals are divided into seven groups each containing six animals. All the animals expect the normal group received Ehrlich ascites carcinoma (EAC) cells $1 \times 10^{6}$ cells/mouse. Group I (normal) received $0.9 \%$ normal saline orally, Group II (control) $0.9 \%$ normal saline orally, Group III treated with standard methotrexate at $2.5 \mathrm{mg} / \mathrm{kg} /$ day p.o, Group IV treated with $250 \mathrm{mg} / \mathrm{kg} /$ day p.o of DCM extract, Group V with $500 \mathrm{mg} / \mathrm{kg} /$ day p.o of DCM extract, Group VI with $1000 \mathrm{mg} / \mathrm{kg} /$ day p.o of DCM extract, and Group VII treated with treated with $2.5 \mathrm{mg} / \mathrm{kg} /$ day p.o of isolated compound. All treatments were given for 9 days [9].

\section{Determination of body weight and mean survival time (MST) of the DCM extract treated mice}

The body weight and MST of each group consisting of six mice were noted. The antitumor efficacy of $M$. pudica was compared to that of methotrexate. The percentage increase life span (\% ILS) of each mouse was calculated using the following equation:

$$
\% \text { Increase in life span }=\frac{T-C}{C} \times 100
$$

Where $\mathrm{T}=$ number of days the treated animals survived and $\mathrm{C}=$ number of days control animals survived.

Determination of viable and nonviable cell count of the DCM extract treated mice

The viability and nonviability of the cells were checked for the above groups by trypan blue assay. The cells were stained with trypan blue
$(0.4 \%$ in normal saline) dye. On staining, the viable cells did not take the stain while the nonviable cells were stained blue and counted using Invitrogen Auto cell counter.

Determination of hematological parameters of the DCM extract treated mice

At the end of the experimental period, the next day after an overnight fasting, blood was withdrawn from the retro-orbital plexus and used for the estimation of hemoglobin ( $\mathrm{Hb}$ ) content, red blood cell (RBC) count and white blood cell (WBC) count using an automatic analyzer. Half of the animals from each group were sacrificed and checked for tumor volume.

\section{Histopathological study of the DCM extract treated mice}

A part of the dissected liver from sacrificed animals of all the groups was cleared off of the surrounding tissues and kept in $10 \%$ buffered neutral formalin, dehydrated in alcohol, and then embedded in paraffin. The paraffin blocks were sectioned at a size of $5 \mu \mathrm{m}$ and stained with hematoxylin and eosin dye and observed under a light microscope for the array of hepatic cords radiating from the central vein and size of sinusoids.

Immunostimulatory activity of DCM extracts of $M$. pudica flower and its isolated compound

Experimental protocol

Mice were divided into seven groups, each containing six animals. Group I (control) was given 1\% sodium carboxymethyl cellulose in water $(0.3 \mathrm{ml} /$ mouse) for 7 days, Group II was administered with $2.5 \mathrm{mg} / \mathrm{kg} /$ day p.o of immunogen and marked as positive standard, Group III was negative standard administered with $2.5 \mathrm{mg} / \mathrm{kg} /$ day p.o of cyclophosphamide, and Groups IV-VI were administered with 250, 500 , and $1000 \mathrm{mg} / \mathrm{kg} /$ day p.o. dosage of DCM extracts for seven days. Group VII was administered with isolated compound at the dose of $2.5 \mathrm{mg} / \mathrm{kg} /$ day p.o. At the end of seven days, mice of all the groups were studied for immunostimulatory activity [10].

\section{In vivo carbon clearance test}

At the end of 7 days, mice of all the groups were injected via the tail vein the carbon ink suspension $(10 \mu \mathrm{l} / \mathrm{g}$ body weights). Blood samples were drawn (in EDTA solution $5 \mu \mathrm{l}$ ) from the retro-orbital vein at intervals of 0 and 15 minutes, a $25 \mu \mathrm{l}$ sample was mixed with $0.1 \%$ sodium carbonate solution $(2 \mathrm{ml})$, and their absorbance was measured at $660 \mathrm{~nm}$. The carbon clearance was calculated using the equation: $\left(\log _{\mathrm{e}} \mathrm{OD}-\log _{\mathrm{e}} \mathrm{OD}_{2}\right) / 15$, where $\mathrm{OD}_{1}$ and $\mathrm{OD}_{2}$ are the optical densities at 0 and 15 minutes, respectively $[11,12]$.

\section{Humoral antibody (HA) titer test}

The animals of all the groups were immunized by injecting $0.1 \mathrm{ml}$ of sheep RBCs (SRBCs) suspension containing $1 \times 10^{8}$ cells intraperitoneally on day 0 . Blood samples were collected in microcentrifuge tubes from an individual animal of all the groups by retro-orbital vein puncture on day 8. The blood samples were centrifuged, and serum was separated. Antibody levels were determined by the hemagglutination technique. Briefly, equal volumes of $(50 \mu \mathrm{l})$ individual serum samples of each group were polled. To serial two-fold dilutions of pooled serum samples made in $50 \mu \mathrm{l}$ volumes of RPMI-1640 in microtitration plates, $50 \mu \mathrm{l}$ of $1 \%$ suspension of SRBC in RPMI-1640 was added. After mixing, the plates were incubated at $37^{\circ} \mathrm{C}$ for $1 \mathrm{hr}$ and examined for hemagglutination under a microscope (button formation). The reciprocal of highest dilution, just before the button formation, was observed as the titer values of the test samples [13].

\section{Delayed type hypersensitivity (DTH) test}

The experiment of DTH was commenced after the HA titer model in the same animals. On day 8, the thickness of the right hind footpad was measured using vernier caliper. The mice were then challenged 
by injection of $1 \times 10^{8}$ SRBCs in the right hind footpad. The footpad thickness was measured again after $24 \mathrm{hrs}$ and $48 \mathrm{hrs}$ of the challenge. The difference between the pre- and post-challenge footpad thickness expressed in mm was taken as a measure of DTH response [14,15].

\section{Neutrophil adhesion test}

The mice were pre-treated orally with vehicle or extracts for 14 days as above. At the end of treatment day 14, blood samples were collected from the retro-orbital plexus into heparinized vials and analyzed for differential leukocyte count (DLC). After the initial counts, blood samples were incubated with $80 \mathrm{mg}$ nylon fibers/ml for 15 minutes at $37^{\circ} \mathrm{C}$. The incubated blood samples were again analyzed for TLC and DLC, respectively, to give neutrophil index of blood samples. The percent neutrophil adhesion was calculated as follows:

$$
\text { Neutrophil adhesion } \%=\frac{\mathrm{NI}_{\mathrm{u}}-\mathrm{NI}_{\mathrm{t}}}{\mathrm{NI}_{\mathrm{u}}} \times 100
$$

Where $\mathrm{NI}_{u}$ is the neutrophil index of untreated blood samples and $\mathrm{NI}_{t}$ is the neutrophil index of treated blood samples $[16,17]$.

\section{Statistical analysis}

Data analysis was performed using Graph Pad Prism software, and the data were expressed as a mean \pm standard error. The significance level of treatment effect was determined by one-way analysis of variance; $\mathrm{p}<0.05$ was considered statistically significant.

\section{RESULTS}

\section{Acute dose toxicity study}

The DCM extract did not show any toxic reactions and mortality up to a dose of $2000 \mathrm{mg} / \mathrm{kg}$ for the extract and $10 \mathrm{mg} / \mathrm{kg}$ for the isolated compound. No changes in food consumption, water intake or behavior (tremors, convulsions, salivation, diarrhea, lethargy, sleep, and coma) were observed in the mice after dose administration. Hence, DCM $250 \mathrm{mg} / \mathrm{kg}$, $500 \mathrm{mg} / \mathrm{kg}$, and $1000 \mathrm{mg} / \mathrm{kg}$ were taken as treatment dose for this study.

\section{Anticancer activity of DCM extract of $M$. pudica}

Administration of DCM extract at the doses of $500 \mathrm{mg} / \mathrm{kg}, 1000 \mathrm{mg} / \mathrm{kg}$ and isolated compound at $2.5 \mathrm{mg} / \mathrm{kg}$ significantly decreased the tumor volume and viable cell count and increases the nonviable cell count in dose treated mice when compared with control group (Table 1). Further, the MST was increased to 29.76 (\% ILS=59.32\%) for $500 \mathrm{mg} / \mathrm{kg}$ group, 35.36 (\% ILS=76.39\%) for $1000 \mathrm{mg} / \mathrm{kg}$ group, and 36.74 (82.43) for the isolated compound on oral administration. After treatment with DCM extract at the doses, $500 \mathrm{mg} / \mathrm{kg}, 1000 \mathrm{mg} / \mathrm{kg}$ and isolated compound at $2.5 \mathrm{mg} / \mathrm{kg}$ in EAC-bearing mice significantly increased the RBC count and $\mathrm{Hb}$ content $(\mathrm{p}<0.05)$ and significantly reduced the WBC count as compared with the EAC control group (Table 2). In EAC treated mice liver section showed dilation and congestion in the central and portal veins of the liver with respect to control mice (Fig. 1a and b). The microscopic examination of liver reveled thickening in hepatic capsule with inflammatory and pigmented cells as well as with diffuse Kupffer cells. The treatment with DCM extracts has reduced most of the pathological alteration observed in EAC control group. The liver section showed few inflammatory cells infiltration in the hepatic parenchymal associated with slight congestion in the central vein (Fig. 1d and e). The treatment group of DCM 1000 and isolated compound shows a normal array of hepatic cord radiating from the central vein and smaller sinusoids (Fig. If and g). The anticancer activity of the M. pudica at the concentration of DCM 500 and DCM 1000 was found to be equipotent with the standard drug methotrexate at $2.5 \mathrm{mg} / \mathrm{kg}$ concentration (Fig. 1c).

\section{Immunostimulatory activity of DCM extracts of M. pudica flower} and its isolated compound

The results revealed that animals treated with doses of the extracts at 500 and $1000 \mathrm{mg} / \mathrm{kg}$ show much increase rate of carbon clearance (Fig. 2 ) from blood ( $0.03986 \pm 0.0017$ and $0.04328 \pm 0.0035$, respectively). The isolated compound also shows increase in carbon clearance rate $(0.05462 \pm 0.0043)$. Treatment of mice with DCM extracts of the plant at $250-1000 \mathrm{mg} / \mathrm{kg}$ doses and isolated compound at $2.5 \mathrm{mg} / \mathrm{kg}$ doses shows much increase in HA titer value as evident from hemagglutination after incubation of serum with SRBCs (Fig. 3). In DTH response test the extract showed statistically significant increase in mean paw edema in dose-dependent manner $(0.37 \pm 0.04$ for $24 \mathrm{hrs}$, and $0.28 \pm 0.02$ for $48 \mathrm{hrs}$ with $1000 \mathrm{mg} / \mathrm{kg}, 0.34 \pm 0.05$ for $24 \mathrm{hrs}$ and $0.25 \pm 0.03$ for $48 \mathrm{hrs}$ with $500 \mathrm{mg} / \mathrm{kg}$ and $0.28 \pm 0.03$ for $24 \mathrm{hrs}$, and $0.27 \pm 0.03$ for $48 \mathrm{hrs}$ with $250 \mathrm{mg} / \mathrm{kg}$ doses of DCM extract of M. pudica) in mice, as compared with $(0.42 \pm 0.21$ for $24 \mathrm{hrs}$ and $0.34 \pm 0.08$ for $48 \mathrm{hrs}$, respectively) the standard drug immunogen at a concentration of $2.5 \mathrm{mg} / \mathrm{kg}$ (Table 3).

Table 1: Effect of DCM extract of M. pudica on tumor weight, MST and life span of EAC-bearing mice

\begin{tabular}{llll}
\hline S. No. & Treatment & Tumor weight $(\mathbf{g})$ & MST (days) \\
\hline 1. & EAC control & $7.29 \pm 0.256$ & $16.44 \pm 0.016$ \\
2. & Methotrexate $2.5 \mathrm{mg} / \mathrm{kg}$ & $2.46 \pm 0.087$ & $38.98 \pm 0.032$ \\
3. & DCM 250 & $5.76 \pm 0.018$ & $20.32 \pm 0.127$ \\
4. & DCM 500 & $4.91 \pm 0.023$ & $29.76 \pm 0.098$ \\
5. & DCM 1000 & $2.98 \pm 0.189^{*}$ & $35.36 \pm 0.012^{*}$ \\
6. & Isolated compound 2.5 & $2.93 \pm 0.134^{*}$ & $36.74 \pm 0.122$ \\
\hline
\end{tabular}

Values are mean \pm SEM of 3 replicates. ${ }^{*} p<0.05$. DCM 250: Dichloromethane extract of . pudica at $250 \mathrm{mg} / \mathrm{kg}$, DCM 500: Dichloromethane extract of $M$. pudica at $500 \mathrm{mg} / \mathrm{kg}$, DCM 1000: Dichloromethane extract of M. pudica at $1000 \mathrm{mg} / \mathrm{kg}$. SEM: Standard error of mean, MST: Mean survival time, EAC: Ehrlich ascites carcinoma, M. pudica: Mimosa pudica

Table 2: Effect of DCM extracts of M. pudica on hematological parameters of EAC treated mice

\begin{tabular}{|c|c|c|c|c|c|c|c|}
\hline S. No. & Treatment & $\begin{array}{l}\text { RBC count } \\
\left(1 \times 10^{6} \text { cells } / \mathrm{mm}^{3}\right)\end{array}$ & $\begin{array}{l}\text { WBC count } \\
\left(1 \times 10^{3} \text { cells } / \mathrm{mm}^{3}\right)\end{array}$ & $\begin{array}{l}\text { Viable cells } \\
\left(1 \times 10^{7} \text { cells } / \mathbf{m m}^{3}\right)\end{array}$ & $\begin{array}{l}\text { Nonviable cells } \\
\left(1 \times 10^{7} \text { cells } / \mathbf{m m}^{3}\right)\end{array}$ & $\begin{array}{l}\text { Hemoglobin } \\
\text { (g/dl) }\end{array}$ & $\begin{array}{l}\text { Tumor } \\
\text { volume (ml) }\end{array}$ \\
\hline 1. & EAC control & $2.84 \pm 0.072$ & $26.31 \pm 0.237$ & $7.52 \pm 0.172$ & $1.52 \pm 0.012$ & $4.37 \pm 0.237$ & $8.23 \pm 0.014$ \\
\hline 2. & Methotrexate $2.5 \mathrm{mg} / \mathrm{kg}$ & $8.76 \pm 0.078$ & $12.98 \pm 1.012$ & $2.60 \pm 0.043$ & $5.32 \pm 0.98$ & $13.27 \pm 0.086$ & $1.94 \pm 0.139$ \\
\hline 3. & DCM 250 mg/kg & $3.18 \pm 0.059$ & $25.73 \pm 0.068$ & $5.98 \pm 0.217$ & $2.74 \pm 1.243$ & $6.79 \pm 0.165$ & $5.14 \pm 0.025$ \\
\hline 4. & DCM $500 \mathrm{mg} / \mathrm{kg}$ & $6.14 \pm 0.019^{*}$ & $15.72 \pm 0.142$ & $3.74 \pm 1.078$ & $4.67 \pm 0.189$ & $8.63 \pm 0.156$ & $3.46 \pm 0.135$ \\
\hline 5. & DCM $1000 \mathrm{mg} / \mathrm{kg}$ & $7.46 \pm 0.139 *$ & $13.47 \pm 0.037 *$ & $2.36 \pm 0.062 *$ & $6.74 \pm 0.072^{*}$ & $11.97 \pm 0.337$ & $2.25 \pm 0.153^{*}$ \\
\hline 6. & $\begin{array}{l}\text { Isolated compound } \\
2.5 \mathrm{mg} / \mathrm{kg}\end{array}$ & $8.23 \pm 0.136^{*}$ & $11.92 \pm 0.145^{*}$ & $2.25 \pm 0.128^{*}$ & $4.93 \pm 0.0125$ & $12.32 \pm 0.271$ & $1.84 \pm 0.012^{*}$ \\
\hline
\end{tabular}

Values are mean \pm SEM of 3 replicates. ${ }^{*}$ p<0.05. DCM 250: Dichloromethane extract of $M$. pudica at $250 \mathrm{mg} / \mathrm{kg}$, DCM 500: Dichloromethane extract of $M$. pudica at $500 \mathrm{mg} / \mathrm{kg}$, DCM 1000: Dichloromethane extract of M. pudica at $1000 \mathrm{mg} / \mathrm{kg}$. SEM: Standard error of mean, EAC: Ehrlich ascites carcinoma, M. pudica: Mimosa pudica, RBC: Red blood cell, WBC: White blood cell 
Table 3: Effect of DCM extract of M. pudica and isolated compound 2 on delayed type hypersensitivity

\begin{tabular}{|c|c|c|c|c|}
\hline \multirow[t]{2}{*}{ S. No. } & \multirow[t]{2}{*}{ Treatment } & \multirow[t]{2}{*}{ Dose (mg/kg) } & \multicolumn{2}{|c|}{ Mean of right footpad thickness (mm) } \\
\hline & & & $24 \mathrm{hrs}$ & $48 \mathrm{hrs}$ \\
\hline 1. & Control & - & $0.16 \pm 0.05$ & $0.16 \pm 0.02$ \\
\hline 2. & Sensitized control & - & $0.26 \pm 0.12$ & $0.23 \pm 0.02 * *$ \\
\hline 3. & + Std & 2.5 & $0.42 \pm 0.09^{*}$ & $0.34 \pm 0.08$ \\
\hline 4. & - Std & 2.5 & $0.17 \pm 0.07$ & $0.17 \pm 0.04^{*}$ \\
\hline 5. & DCM 250 mg/kg & 250 & $0.28 \pm 0.03$ & $0.27 \pm 0.03$ \\
\hline 6. & DCM 500 mg/kg & 500 & $0.34 \pm 0.05^{* *}$ & $0.25 \pm 0.03^{* *}$ \\
\hline 7. & DCM $1000 \mathrm{mg} / \mathrm{kg}$ & 1000 & $0.37 \pm 0.04^{*}$ & $0.28 \pm 0.02 *$ \\
\hline 8. & Isolated compound $2.5 \mathrm{mg} / \mathrm{kg}$ & 1000 & $0.39 \pm 0.15^{*}$ & $0.32 \pm 0.12^{*}$ \\
\hline
\end{tabular}

All values are expressed as mean \pm SEM of three observations. ${ }^{*} \mathrm{p}<0.05,{ }^{* *} \mathrm{p}<0.01$ comparing with the control. DCM 250: Dichloromethane extract of $M$. pudica at $250 \mathrm{mg} / \mathrm{kg}$, DCM 500: Dichloromethane extract of M. pudica at $500 \mathrm{mg} / \mathrm{kg}$, DCM 1000: Dichloromethane extract of M. pudica at $1000 \mathrm{mg} / \mathrm{kg}$. SEM: Standard error of mean, M. pudica: Mimosa pudica

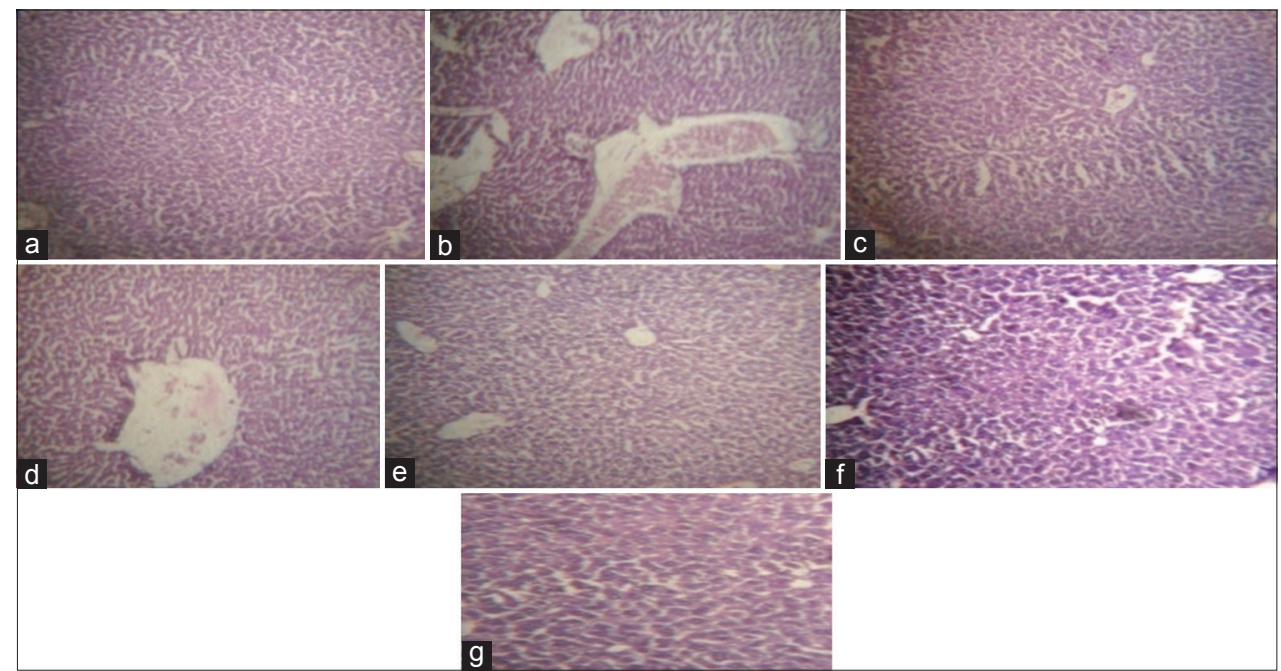

Fig. 1: Histopathological interpretation of dichloromethane (DCM) extracts and compound 2 from Mimosa pudica flower on the liver section of Swiss albino mice. (a) Control: Normal nucleus, hepatocytes are radiating outward from a central vein in the center. (b) Ehrlich ascites carcinoma control: Cellular inflammatory infiltration, nuclear hypertrophy, debris in the central vein, hemorrhages and wide sinusoids. (c) Standard: Cytoplasmic degeneration has been reduced, mild cellular inflammatory infiltration and nuclei of hepatic cells are better. (d) DCM 250: Cellular inflammatory infiltration, moderate nuclear hypertrophy, little debris in the central vein and wide

sinusoids. (e) DCM 500: Cytoplasmic degeneration has nearly reduced mild cellular inflammatory infiltration and normal array of hepatic cords radiating from the central vein. (f) DCM 1000: Relatively small sinusoids, cellular hemorrhage is not very prominent, no debris in the central vein and mild cellular inflammatory infiltration. (g) Compound 2. Very small sinusoids, cellular hemorrhage is not very prominent, no debris in the central vein and mild cellular inflammatory infiltration

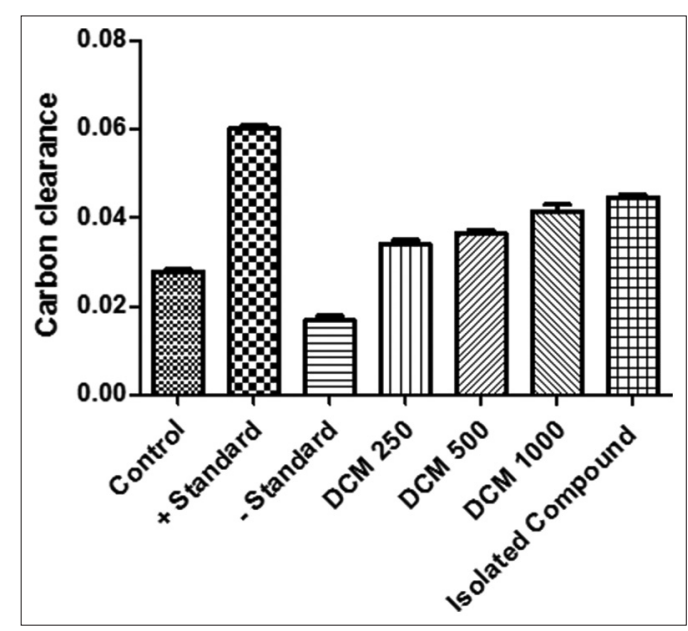

Fig. 2: Results for carbon clearance test (absorbance) for dichloromethane extracts of Mimosa pudica and isolated compound. DCM 250: Dichloromethane extract of M. pudica at $250 \mathrm{mg} / \mathrm{kg}$, DCM 500: Dichloromethane extract of M. pudica at $500 \mathrm{mg} / \mathrm{kg}$, DCM 1000: Dichloromethane extract of M. pudica at $1000 \mathrm{mg} / \mathrm{kg}$
Isolated compound also exhibits good response for DTH response $(0.39 \pm 0.15$ for $24 \mathrm{hrs}$ and $0.32 \pm 0.12$ for $48 \mathrm{hrs}$ ). In neutrophil adhesion test, the incubation of blood with nylon fibers produced a decrease in the neutrophil counts due to adhesion of neutrophils to the fibers. All the doses of DCM extract of M. pudica showed a significant increase in the neutrophil adhesion when compared to standard drug immunogen and isolated compound (Fig. 4).

The results thus depict a good anticancer and immunostimulatory activity of DCM extracts of flower of M. pudica and its isolated compound $11 \beta$ hydroxy-3 methoxy 1,2 dehydro crinane.

\section{DISCUSSION}

Many plant products used in traditional medicine as anticancer agents have been reported to have immunostimulatory activities. The immunotherapeutic properties of these plants extracts initiate the enhancement of anticancer response by inhibiting secretions of inhibitory cytokines and recruitment of immune cells in the tumor site. In this study, we found that DCM extracts of M. pudica significantly shows both anticancer and immunostimulatory activity in experimental mice which gives a strong evidence for the traditional usage of immunostimulatory anticancer drugs. 


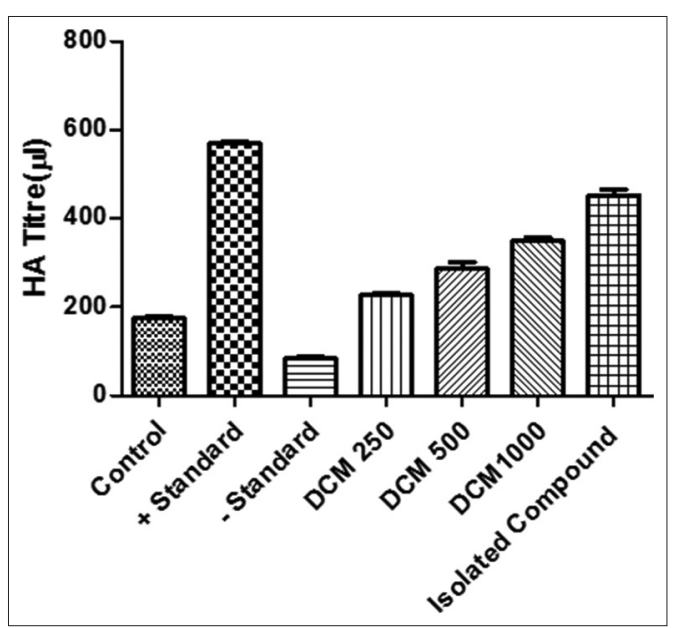

Fig. 3: Results for humoral antibody titer test for dichloromethane extracts of Mimosa pudica and isolated compound 2.

DCM 250: Dichloromethane extract of M. pudica at $250 \mathrm{mg} / \mathrm{kg}$ DCM 500: Dichloromethane extract of $M$. pudica at $500 \mathrm{mg} / \mathrm{kg}$, DCM 1000: Dichloromethane extract of $M$. pudica at $1000 \mathrm{mg} / \mathrm{kg}$

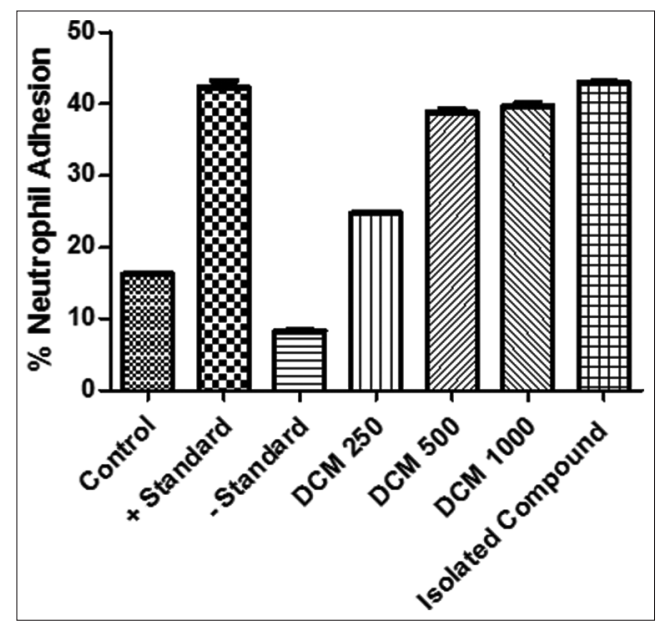

Fig. 4: Results for \% neutrophil adhesion for dichloromethane extracts of Mimosa pudica and isolated compound.

DCM 250: Dichloromethane extract of $M$. pudica at $250 \mathrm{mg} / \mathrm{kg}$, DCM 500: Dichloromethane extract of $M$. pudica at $500 \mathrm{mg} / \mathrm{kg}$, DCM 1000: Dichloromethane extract of M. pudica at $1000 \mathrm{mg} / \mathrm{kg}$

The results from the acute dose toxicity study reveals that the animals treated with the DCM extract at a higher dose of $2000 \mathrm{mg} / \mathrm{kg}$ and isolated compound at $2.5 \mathrm{mg} / \mathrm{kg}$, did not produce any significant toxicity signs, behavioral changes, body weight changes, or macroscopic findings during the observational period. Hence, the $\mathrm{LD}_{50}$ of DCM extract of M. pudica and isolated compound should be more than $2000 \mathrm{mg} / \mathrm{kg}$ and $10 \mathrm{mg} / \mathrm{kg}$, respectively.

This study indicated that the DCM extracts of flowers of $M$. pudica have significantly enhanced the erythrocyte count and $\mathrm{Hb}$ level when compared to that of EAC control indicating the apoptosisinducing capacity of the extract. Viable cell count was decreased, and nonviable cell count was increased in intraperitoneal fluid by the plant extracts in a dose-dependent manner. This indicated a toxic effect on these cells that resulted in cell death. It signifies that the drug was absorbed directly by the EAC cells in the peritoneal cavity and causes the lysis of the EAC cell by the direct cytotoxic mechanism. The antitumor activity of the plant extracts at 500 and $1000 \mathrm{mg} / \mathrm{kg}$ and isolated compound at $2.5 \mathrm{mg} / \mathrm{kg}$ body weight dose was effective as the standard drug methotrexate suggesting its potent activity as an antitumor agent. The histopathological examination of the liver section revels that the extract treated mice group shows normal array of hepatic cord radiating from the central vein and smaller sinusoids in a dose-dependent manner which signifies the replacement of cancerous cells with normal cells (Bhadoriyal and Mandoriya, 2012).

Further, the study reveals that the extracts $(250-1000 \mathrm{mg} / \mathrm{kg})$ and isolated compound $(2.5 \mathrm{mg} / \mathrm{kg})$ evoked a significant increase in percent neutrophil adhesion and rate of carbon clearance. This may potentially help in increasing immunity of body against microbial infections by upregulation of $\beta_{2}$ integrins present on the surface of the neutrophil. The high values of hemagglutinating antibody titer obtained in the case of the plant's extracts and isolated compound have indicated that immunostimulation was achieved through humoral immunity. The increase in DTH reaction in mice in response to SRBC antigen revealed significant paw edema $(p<0.05)$ in the dosedependent manner $(250-1000 \mathrm{mg} / \mathrm{kg}$ ) for the plant's extracts and isolated compound at $2.5 \mathrm{mg} / \mathrm{kg}$. In this study, we found that DCM extracts and isolated compound modulate both cellular and humoral immunity in experimental mice. Thus, the DCM extract of flowers of M. pudica and isolated compound $11 \beta$ hydroxy- 3 methoxy 1,2 dehydro crinane can be a promising anticancer agent with immunostimulant property.

\section{CONCLUSION}

In this work, it is observed that anticancer activity of M. pudica Linn. (Fabaceae) is due to the stimulation of macrophages which are the important cells for the immune system. Thus, this study can further be proceed for a better understanding of anticancer and immunostimulatory mechanism of M. pudica which can be a boon for the human society.

\section{ACKNOWLEDGMENT}

The author sincerely thanks Girijananda Chowdhury Institute of Pharmaceutical Science, Guwahati, Assam, India, for providing all facilities to carry out this study.

\section{REFERENCES}

1. Muhit A, Apurba S, Saiful MI, Muniruddin A. Cytotoxity and antimicrobial activity of the crude extract of Abutilon indicum. Int $\mathrm{J}$ Pharmacogn Phytochem Res 2010;2:14-20.

2. Chowdhury S, Saha D, Paul S. In vitro cytotoxic activities of methanolic extract of Mimosa pudica. Bull Pharm Res 2012;2 Suppl 1:42-5.

3. Shukla S, Mehta A, John J, Mehta P, Vyas SP, Shukla S. Immunomodulatory activities of the ethanolic extract of Caesalpinia bonducella seeds. J Ethnopharmacol 2009;125(2):252-6.

4. Zaveri M, Gohil P, Jain S. Immunostimulant activity of n-butanol fraction of root bark of Oroxylum indicum. Vent. J Immunotoxicol 2006;3(2):83-99

5. Joseph B, George B, Mohan J. Pharmacology and traditional use of Mimosa pudica. Int J Pharm Sci Drug Res 2013;5 Suppl 2:41-4.

6. Parmer F, Kushawaha N, Highland H, George LB. In vitro antioxidant and anticancer activity of M. Pudica extract. Int J Pharm Res 2014;7 Suppl 11:50-2.

7. Ramesh B, Pratheeba M. Studies on antimicrobial and anticancer activity of Solanum trilobatium. Asian J Pharm Clin Res 2014;7 Suppl 1:213-9.

8. Muthukumaran P, Shanmuganathan P, Malathi C. In vitro antioxidant evaluation of Mimosa pudica. Asian J Pharm Res 2011;2 Suppl 1:44-6.

9. Azmi L, Singh MK, Akhtar AK. Pharmacological and biological overview on Mimosa pudica Linn. Int J Pharm Life Sci 2011;2 Suppl 1:1226-34.

10. Lu Y, Fan J, Zhao Y, Chen S, Zheng X, Yin Y, et al. Immunomodulatory activity of aqueous extract of Actinidia macrosperma. Asia Pac J Clin Nutr 2007;16 Suppl 1:261-5.

11. Yusatina SR, Subagus W, Sitarina W, Agustinus Y. In vivo immunomodulatory effect and histopathological features of mouse liver and kidney treated with neolignans isolated from 
red betel (Piper crocatum Ruiz and Pav) Leaf. Trop J Pharm Res 2014;13 Suppl 10:1609-14

12. Sahu RK, Nahak G. Effect of Ocimum sanctum Linn. Leaf extract in Clarias batrachus Linn. Asian J Pharm Clin Res 2014;7 Suppl 3:157-63.

13. Jayathirtha MG, Mishra SH. Preliminary immunomodulatory activities of methanol extracts of Eclipta alba and Centella asiatica. Phytomedicine 2004;11(4):361-5.

14. Patel P, Asdaq SM. Immunomodulatory activity of methanolic fruit extract of Aegle marmelos in experimental animals. Saudi Pharm J
2010;18(3):161-5.

15. Bhadoriyal SS, Mandoriya M. Immunomodulatory effect of Tricosanthes dioica Roxb. Asian Pac J Trop Biomed 2012;7:985-7.

16. Yang XQ, Zheng H, Ye Q, Li RY, Chen Y. Chloroquinone inhibits cell proliferation and induces apoptosis in nasopharyngeal carcinoma cell lines. Trop J Pharm Res 2015;14 Suppl 12:2187-92.

17. Nayak S, Mengi S. Immunostimulant activity of the extracts and bioactives of the fruits of Morinda citrifolia. Pharm Biol 2009;47 Suppl 3:248-54 